\section{Academic living}

THE most striking feature of Swiss academic life is that its practitioners are well paid. Salaries of professors begin at about SFr 150,000 a year, comparable with those paid at all but the most well-heeled of universities elsewhere in the world.

The Swiss say that there is no alternative: the universities have to be able to recruit people from where they choose. What this implies is that the cantonal universities must be in a position to recruit people from universities elsewhere, while the two polytechnics must be able to attract successful engineers (more often Swiss) from successful industry.

More than that, appointment as a professor at a Swiss university carries with it not merely prestige and an endowment in equipment but ample opportunity for research. And at least some cantons are prepared, on behalf of senior academics, to relax the usual rules preventing incomers from buying houses and apartments without having lived in Switzerland for five years, or their spouses from taking paid employment.

At least in money terms, much the same applies to more junior academic scientists. At the University of Geneva, for example, a teaching assistant (appointed for a maximum of five years) could expect to earn SFr4,000 a month, say SFr 50,000 a year, while preparing a doctoral thesis. This is in accord with what seems to be a general principle of Swiss life, that the disparity between the salaries of senior and junior people is less apparent than elsewhere.

Can there be, in such halcyon circumstances, discontents? Sadly, but inevitably, there are. The most common is that the many people occupying university posts below the rank of professor or those on postdoctoral fellowships foresee only a bleak future. On one estimate, there may be 10 able scientists in the system for each chair likely to become vacant in the next 15 or 20 years. But the prospects of promotion are made worse by the inclination of Swiss universities to recruit academics from elsewhere, a potentially bruising issue which remains unresolved.

There are also worries about the administration of the universities. No canton has more than one university (and most have none), with the result that the institution tends to be regarded by the canton government as its department of higher education. The result of that is a degree of closeness in the relationship between universities and cantons that requires the university administration to present a bureaucratic face to the outside and thus, internally, to be aloof - sometimes highhanded in its internal dealings, sometimes over-cautious. It is perhaps as well that "freedom of research" is guaranteed by the law.

J.M.

University of Zurich

\title{
University education for all?
}

RESIDENTS of Zurich take higher education seriously. In 1970, they voted to spend SFr600 million to build a new science campus on farmland just outside the city centre. Until recently, they spent a remarkable 10 per cent of the canton's budget on the University of Zurich. The figure has dropped to 8 per cent, but even University Rector Hans Schmid, a theologian, admits "there have to be some limits". Zurich is the largest of Swiss universities, with almost 20,000 students. Between the University of Zurich and ETH, a quarter of all those enrolled in Swiss universities study in Zurich.

But, although ETH has a higher profile in the world at large, there is no enmity between the two institutions: they share facilities in a number of disciplines and make common arrangements for dormitory space and the like. "We look at them like a younger sister", says university secretary Maximilian Jaeger. (The university was founded in 1833,22 years before ETH.) The science campus at Irchel is nearly complete. The third and last section should be ready for occupation by molecular biology, physics, mathematics and other faculties in March 1989. One molecular biologist called it "astounding" that the university could put together enough land so close to the city centre. Once the move is complete, the city centre campus, adjacent to ETH, will house only humanities and social sciences.

The university has been subject to tremendous growth - the number of students has increased fivefold in 25 years - in part due to a quirk of the Swiss university system. Unlike in West Germany and other countries, there are no quotas to limit the numbers of students in particular fields. Even in medicine, anyone who wants to study can do so for a nominal fee the number of students has surged to 2,600 in medicine and dentistry. But by and large a good education can be had by all - there is a mechanism to divert excess medical students to other universities.

Natural scientists have remained mostly unaffected by the student boom. Noted molecular biologist Charles Weissmann, a Swiss native who returned from New York University in the early 1970 s, spoke of "generous" support and good facilities. Not so in the humanities and social sciences, where Schmid says "education has suffered" because of the overload.

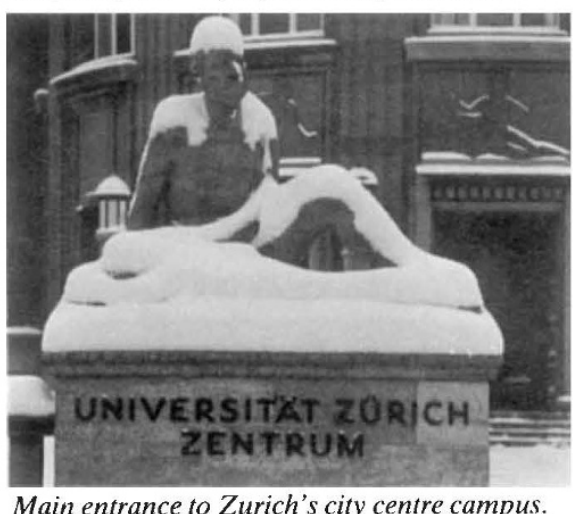

Main entrance to Zurich's city centre campus.

Student/faculty ratios are up to 120 to 1 or even 150 to 1 in economics and psychology. The law and German departments are also overburdened. Research has necessarily been pushed aside to make room for the extraordinary teaching load.

The university administration hopes the numbers will stabilize in the coming years. Jaeger says "we hope that the big problems are behind us". This is not inevitable despite the passing of the "baby boom" generation. The student body is changing demographically, with more women studying and older people returning for second degrees. And some cantons are still striving to increase their educated population - an interesting phenomenon in a country that appears uniformly wealthy and successful to a casual visitor.

S.D.

\section{Basle University}

\section{A victim of local tensions}

BASLE has a small university with a very long history. Founded in 1460 by a papal bull from Pope Pius II, Basle predates Lausanne by more than 70 years as the oldest Swiss university. As Enea Silvio Piccolomini, Pope Pius II had been secretary to the Basle Council from 1431 to 1449. Residents clamoured for the honour of a university (which in those days had to be created by the pope or an emperor) and the pope granted their wish. Even then, there was dissent among Basle's citizens over the advisability of such a large and expensive undertaking.

Five centuries later, support for the university remains a politically hot issue in the divided canton of Basle. Some historical background is in order. As in other Swiss cities in the nineteenth century, war broke out in 1833 between the city of Basle (Basle-Stadt) and its hinterlands (Basle-Landschaft) that led to a partition. A division of the university's worldly goods similar to a modern-day divorce proceeding was avoided only through the intervention of the Swiss Confederation and the payment of a ransom by BasleStadt to Basle-Landschaft.

Basle has lagged behind other cities in resolving the country-city differences. 